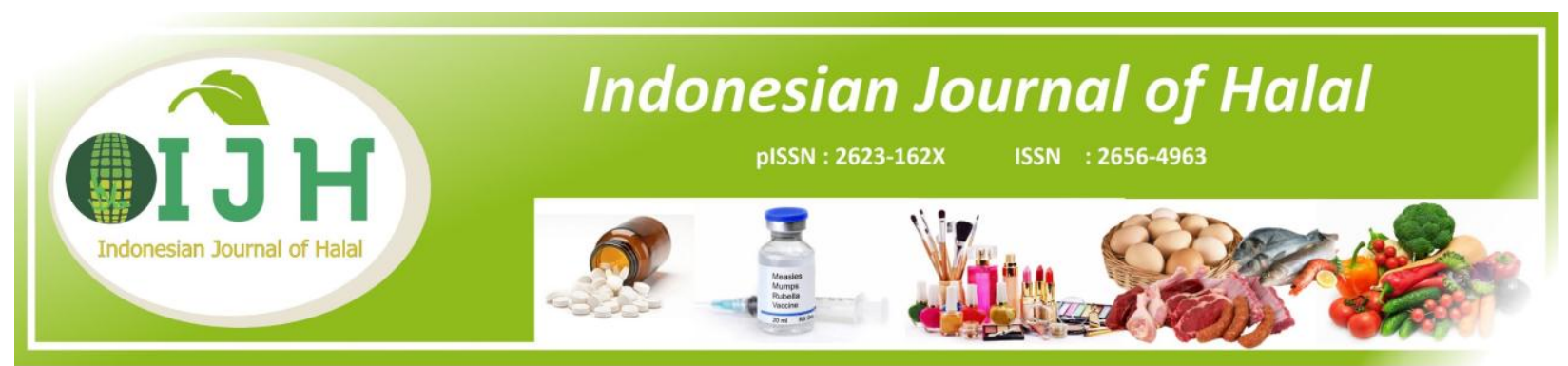

\title{
Real Time-Polymerase Chain Reaction (RT-PCR) sebagai Alat Deteksi DNA Babi dalam Beberapa Produk Non-Pangan
}

\author{
Widayat $^{1,5 *)}$, Tri Winarni Agustini ${ }^{2,5)}$, Meiny Suzery ${ }^{3,5)}$, Ahmad Ni’matullah Al-Baarri ${ }^{4,5)}$, Sylvia \\ Rahmi Putri ${ }^{5)}$ dan Kurdianto ${ }^{6}$ \\ ${ }^{1)}$ Departemen Teknik Kimia, Fakultas Teknik, Universitas Diponegoro \\ ${ }^{2)}$ Departemen Teknologi Hasil Perikanan, Fakultas Perikanan dan Ilmu Kelautan, Universitas \\ Diponegoro \\ ${ }^{3)}$ Departemen Kimia, Fakultas Sains dan Matematika, Universitas Diponegoro \\ 4) Program Studi Teknologi Pangan, Fakultas Peternakan dan Pertanian, Universitas Diponegoro \\ ${ }^{5)}$ Pusat Kajian Halal UPT Laboratorium Terpadu, Universitas Diponegoro \\ ${ }^{6)}$ PT Sciencewerke Jl Palmerah Barat 25 Jakarta Barat DKI Jakarta Indonesia \\ *)Penulis Korespodensi : widayat@live.undip.ac.id
}

\begin{abstract}
ABSTRAK
Bagi seorang muslim status halal suatu produk non-pangan salah satunya kosmetik maupun obatobatan sangat mutlak yang harus dipenuhi. Produk yang beredar dipasaran harus terbebas dari kandungan babi atau bahan lain yang menyebabkan produk tersebut tidak lagi halal. Metode Real Time Polymerase Chain Reaction (RT-PCR) yang dapat mendeteksi kandungan babi maupun alkohol untuk dapat memastikan kandungan tersebut terbebas dari cemaran babi. Dalam penelitian ini, telah dilakukan analisis kemungkinan adanya kandungan unsur babi dari ke empat produk non-pangan seperti kapsul, kuas roti, day cream dan sabun kecantikan yang dianalisis menggunakan RT-PCR. Penelitian ini dibagi menjadi dua tahap, tahap awal dilakukan ektraksi DNA dan tahap kedua dilakukan analisis RT-PCR. Didapatkan pada tahap awal ekstraksi DNA, hasil pengukuran dan kemurnian dengan nilai konsentrasi kapsul 2,9 ng/ $\mu \mathrm{I}$; kuas roti sebesar 3,4 ng/ $\mathrm{I}$; day cream sebesar 2,4 ng/ $\mu \mathrm{I}$; dan sampel sabun kecantikan sebesar 2,2 ng/ $\mu \mathrm{I}$. Pada tahap kedua, secara keseluruhan dari ke empat produk yang dipilih secara acak sebagai objek penelitian produk kapsul terbebas dari kandungan babi, kecuali pada produk kuas roti sebesar 3,15\%; day cream sebesar 3,52\%; dan sabun kecantikan sebesar 124,83\% positif tercemar kandungan babi.
\end{abstract}

Kata Kunci ：RT-PCR, DNA babi, non-pangan, halal

\begin{abstract}
Real Time-Polymerase Chain Reaction (RT-PCR) as a Tool for Detecting Pig DNA in NonFood Products. For a Muslim, the halal status of a non-food product is one of the most complete cosmetics or medicines that must be offered. Products that discuss the market must be free from reserves of pork or other ingredients that make the product no longer halal. The Real Time Polymerase Chain Reaction (RT-PCR) method that can calculate pig or alcohol reserves to fill these reserves is free from pig contamination. In this study, an analysis of the content of no pork
\end{abstract}


from non-food products such as capsules, bread brushes, day creams and beauty soaps was analyzed using RT-PCR. This research was divided into two stages, the initial stage was carried out with DNA and the second stage was carried out RT-PCR analysis. Obtained in the early stages of DNA extraction, measurement results and purity with a capsule measurement value of $2.9 \mathrm{ng} / \mu \mathrm{I}$; bread brush of $3.4 \mathrm{ng} / \mu \mathrm{I}$; day cream of $2.4 \mathrm{ng} / \mu \mathrm{I}$; and beauty soap samples of 2.2 $n g / \mu I$. At the second time, all four randomly selected products as the object of research on products were free from pig reserves, except for bread brush products of 3.15\%; day cream at $3.52 \%$; and beauty soap amounting to $124.83 \%$ positive contaminated with pork content.

Keywords $\quad$ : RT-PCR, pig DNA, non-food, halal

\section{PENDAHULUAN}

Indonesia merupakan salah satu negara dengan mayoritas beragama muslim dengan jumlah populasi sebesar 209,1 juta jiwa atau setara $87,2 \%$ dari total penduduk menurut The Pew Forum on Religion Public Life. Tingginya jumlah penduduk muslim di Indoensia berpengaruh pada gaya hidup halal yang menjadi landasan dalam pemilihan produk. Sehingga pemerintah menerbitkan peraturan Undang-Undang Nomor 33 Tahun 2014 tentang Jaminan Produk Halal (UUJPH) yang dapat melindungi dalam pemilihan produk hingga ke tangan konsumen. Status halal sudah menjadi isu global, tak terkecuali pada produk non-pangan seperti obat-obatan hingga kosmetika.

Produk non-pangan bukanlah sesuatu hal yang baru, kosmetik telah dikenal sejak zaman dahulu dan merupakan kebutuhan sekunder, akan tetapi sudah menjadi kebutuhan pokok bagi setiap orang khususnya kaum wanita. Kosmetik merupakan produk yang berinteraksi langsung dengan tubuh melalui kulit, produk bisa saja mengandung zat yang bersifat najis dalam paradigma Islam, salah satunya bahan mentah yang terbuat dari unsur haram. Tidak hanya pada kosmetik, produk obatobatan yang beredar dipasaran menurut data Lembaga Pengkajian Pangan, Obat-obatan, dan Kosmetika Majelis Ulama Indonesia (LPPOM MUI) menunjukkan bahwa saat ini obat yang telah beredar dan memiliki sertifikat halal berjumlah 30 ribu. Minimnya obat yang bersertifikasi halal menggambarkan bahwa kepedulian industri obat tidak mempedulikan persoalan halalharam.

Titik kritis haram yang harus diwaspadai terutama jika bahan dasar berasal dari babi atau bagian organ manusia, maka jenis produk tersebut dinyatakan haram. Berdasarkan QS; Al- Baqarah: 173, penggunaan apapun berasal dari babi adalah haram. Fatwa MUI No. 2/MunasVI/MUI/2000, penggunaan produk yang mengandung atau berasal dari bagian organisme manusi hukumnya adalah haram, apabila berasal dari hewan yang bukan babi jika tidak sembelih secara Islam, maka dinyatakan haram.

Dari faktor-faktor tersebut, peran analisis yang dapat menguji kandungan haram atau kontaminasi bahan diluar dari bahan aslinya sangat dibutuhkan. Upaya melakukan identifikasi telah dilakukan dengan berbagai metode, metode yang dianggap paling valid saat ini adalah metode PCR dengan berbagai variasinya. Polymerase Chain Reaction (PCR) merupakan salah satu teknik amplifikasi asam nukleat in vitro yang paling banyak dipelajari dan digunakan secara luas. PCR digunakan untuk menggandakan jumlah 
molekul DNA pada target tertentu dengan menganalisis molekul DNA baru yang berkomplemen dengan molekul DNA target melalui enzim dan oligonukleotida sebagai primer dalam suatu thermocycle. Panjang target DNA berkisar antara puluhan sampai ribuan nukleotida yang posisinya diapit sepasang primer. Primer yang berada sebelum daerah target disebut primer forward dan yang berada setelah daerah target disebut primer reverse. Enzim yang digunakan sebagai pencetak rangkaian molekul DNA yang baru dikenal disebut enzim polimerase. Proses PCR didahului dengan reverse transcriptase terhadap molekul mRNA sehingga diperoleh molekul complementary DNA (cDNA). Molekul cDNA digunakan dalam proses PCR, pada tahap proses PCR digunakan sebagai pengamplifikasi RNA. Tahap ini dikenal sebagai proses RT-PCR.

Salah satu jenis metode pendeteksi komponen babi dan turunannya bebrbasis DNA menggunakan RT-PCR, memiliki tingkat sensitivitas dan spesifisitas yang tinggi dibandingkan dengan metode lainnya. Pengujian menggunakan RT-PCR telah banyak dilakukan oleh peneliti sebelumnya, seperti penelitian Balia (2014) mengidentifikasi pemalsuan bakso dengan daging babi dengan metode RT-PCR, Cai dkk (2012) mendeteksi dan menghitung jumlah kandungan babi dan gelatin sapi pada campuran gelatin menggunakan metode RT-PCR, Hasan Ibrahem Abdullah Amqizal dkk (2017) mengidentifikasi DNA babi dalam gelatin yang mengandung makanan olahan, dan Patihul Husni dkk (2017) mendeteksi kandungan babi dan alkohol dalam eksipien farmasi dan produk obat. Metode menggunakan RT-PCR pada pangan telah banyak dilakukan pada penelitian sebelumnya, minimnya penelitian mengenai deteksi DNA babi selain produk pangan sehingga perlu dilakukan pengembangan analisis.
Berdasarkan latar belakang mengetahui kandungan DNA babi pada produk non-pangan khususnya kosmetik dan obat-obatan yang beredar dipasaran menggunakan metode Real TimePolymerase Chain Reaction (RT-PCR).

\section{METODE}

Penelitian dilakukan di Pusat Kajian Halal Laboratorium Terpadu Universitas Diponegoro, menggunakan sampel kosmetik yang beredar dipasaran dipilih secara acak, sampel terdiri dari kapsul, kuas roti, day cream, dan sabun kecantikan. Setiap perlakuan dilakukan 1 (satu) kali pengulangan menggunakan CFX96 RealTime PCR system. Penelitian dibagi menjadi dua tahap, yaitu tahap awal dilakukan ekstraksi DNA dan tahap selanjutnya dilakukan analisis RT-PCR.

Sebelum memasuki tahap awal dilakukan pre-running, sampel dilakukan pemotongan menjadi bagian terkecil, diekstraksi dengan menggunakan Progenus EasyFast Extraction for Pharmaceutical PRODUCTS I (Cat. ExtrPharma1), dari hasil tersebut DNA dianalisis menggunakan NanoDrop 2000/2000c Spectrophotomerters hasil ekstraksi DNA dideteksi menggunakan Progenus EasyFast Pig/Suidae Detection \& Quantification Kit, dan dianalisis menggunakan CFX96 Real-Time PCR System.

Tahap awal ekstraksi DNA bertujuan untuk mendapatkan larutan DNA yang dapat digunakan sebagai analisis RT-PCR. Dimana sampel ditambah buffer dengan suhu $65^{\circ} \mathrm{C}$ selama 10 menit, ditambah precipitation buffer dalam es selama 5 menit, sentrifuge selama 2 menit dengan kecepatan $12.000 \mathrm{rpm}$, ditambah bindding buffer lalu sentrifugasi selama 1 menit dengan kecepatan $12.000 \mathrm{rpm}$, ditambah washing buffer 1 dengan kecepatan 12.000 
rpm, menghangatkan elution buffer pada suhu $65^{\circ} \mathrm{C}$, inkubasi pada suhu $65^{\circ} \mathrm{C}$ dengan kecepatan $12.000 \mathrm{rpm}$.

Tahap kedua, setelah didapatkan larutan DNA selanjutnya dilakukan analisis $60^{\circ} \mathrm{C}$ dengan pengulangan sebanyak 40 siklus. Kalkulasi \% DNA babi pada sempel bersifat semi kuantitatif dengan menggunakan nilai $\mathrm{Ct}$ (cycle threshold) dengan rumus sebagai berikut :

Presentase DNA babi $(\%)=2^{\text {(Ct vertebrate }-\mathrm{Ct} \text { pig })} \times 100$

Dimana hasil running qPCR dinyatakan valid apabila nilai $\mathrm{Ct}$ (pig) pada kontrol negatif diatas 38 dan nilai $\mathrm{Ct}$ (pig) pada kontrol positif yaitu \pm 30 .
RT-PCR menggunakan larutan MIX, DNAse free water (kontrol negatif), larutan EPC (larutan positif) dengan suhu pada tahap inisial denaturasi dan denaturasi sebesar $95^{\circ} \mathrm{C}$ serta pada tahap annealingekstensi (FAM\&VIC) dengan suhu sebesar

\section{HASIL DAN PEMBAHASAN}

\section{Analisis ekstraksi DNA}

Hasil ekstraksi DNA menggunakan Progenus EasyFast Extraction for Pharmaceutical Products I dapat dilihat pada tabel 1, berdasarkan hasil pengukuran konsentrasi DNA pada keempat sampel didapatkan hasil ekstraksi DNA dengan nilai konsentrasi antara 2,2 - 3,4 ng/ $\mu \mathrm{I}$.

Tabel 1. Hasil pengukuran konsentrasi dan kemurnian sampel DNA

\begin{tabular}{clccc}
\hline No. & \multicolumn{1}{c}{ Sampel } & Konsentrasi $(\mathrm{ng} / \mu \mathrm{I})$ & A260/280 & A260/230 \\
\hline 1 & Kapsul & 2,9 & 1,52 & 0,38 \\
2 & Kuas roti & 3,4 & 1,83 & 0,56 \\
3 & Day cream & 2,4 & 2,16 & 1,95 \\
4 & Sabun Kecantikan & 2,2 & 4,60 & 0,52 \\
\hline
\end{tabular}

Hasil pengukuran kemurnian DNA berdasarkan pada rasio A260/280 berkisar antara 1,52-4,60 sedangkan ratio A260/230 berkisar antara 0,38-1,95. Standar nilai rasio A260/280 yang baik untuk DNA berkisar antara 1,8-2,0. Didapatkan sampel kapsul dan sabun kecantikan memiliki nilai kisaran di luar batas normal, hal ini dapat diakibatkan oleh terbawanya reagen seperti fenol, alkohol, dan kloroform pada saat ekstraksi ke dalam larutan DNA. Faktor lainnya disebabkan keberadaan protein, RNA, dan pengotor lainnya yang berasal dari sampel pada akhir larutan DNA yang dapat mempengaruhi kualitas kemurnian dari DNA.

Nilai pengukuran rasio A260/230 berkisar antara 0,38-1,95; berdasarkan standar nilai rasio A260/230 berkisar antara 2,0-2,2. Berdasarkan hasil pengukuran nilai rasio, sampel yang berada di bawah standar terdapat pada ke empat sampel uji. Hal ini dapat diakibatkan terbawanya residu fenol pada saat ekstraksi atau residu guanidine pada membran kolom. Pada beberapa kasus, nilai rasio A260/230 di bawah standar tidak mempengaruhi terhadap analisis qPCR, sehingga sampel dapat digunakan untuk analisis lanjutan pada qPCR.

\section{Analisis Real-Time PCR}

Hasil amplifikasi qPCR dapat dilihat pada Tabel 2, dimana sampel dilakukan tanpa pengulangan disertai dengan kontrol positif dan kontrol negatif. Hasil menunjukkan bahwa sampel secara acak yang dijual dipasaran didapatkan kuas roti, 
day cream dan sabun kecantikan yang di uji positif tercemar DNA babi, kecuali pada sampel kapsul tidak terdapat cemaran DNA babi.

Tabel 2. Hasil sampel menggunakan EasyFast Pig/Suidae detection \& quantification kit

\begin{tabular}{cccc}
\hline Flour & Target & Sampel & Nilai Cq \\
\hline FAM & Pig & Kontrol positif & 33,31 \\
FAM & Pig & Kontrol negatif & N/A \\
FAM & Pig & Kapsul & N/A \\
FAM & Pig & Kuas roti & 34,60 \\
FAM & Pig & Day cream & 38,23 \\
FAM & Pig & Sabun kecantikan & 37,04 \\
VIC & Vertebrata & Kontrol positif & 32,48 \\
VIC & Vertebrata & Kontrol negatif & N/A \\
VIC & Vertebrata & Kapsul & 34,48 \\
VIC & Vertebrata & Kuas roti & 29,61 \\
VIC & Vertebrata & Day cream & 33,40 \\
VIC & Vertebrata & Sabun kecantikan & 37,36 \\
\hline
\end{tabular}

Keterangan : FAM merupakan DNA babi

VIC merupakan DNA Vetebrata

Kontrol positif dan negatif menunjukkan hasil yang valid sesuai dengan rekomendasi kit, yaitu $\mathrm{Cq}$ FAM dan VIC \pm 30 untuk kontrol positif dan Cq FAM dan VIC>38 pada kontrol negatif. Berdasarkan hasil amplifikasi yang ditunjukkan pada tabel 2, sampel yang memiliki cemaran DNA babi terbesar pada sampel day cream dengan nilai Cq FAM sebesar 38,23. Sampel dengan hasil cemaran DNA babi terendah didapatkan pada kuas roti dengan nilai $\mathrm{Cq}$ FAM sebesar 34,60. Kurva amplifikasi pada sampel kuas roti, day cream, dan sabun kecantikan yang tercemar DNA babi dapat dilihat pada Gambar 1,2, dan 3.

\section{Amplification}

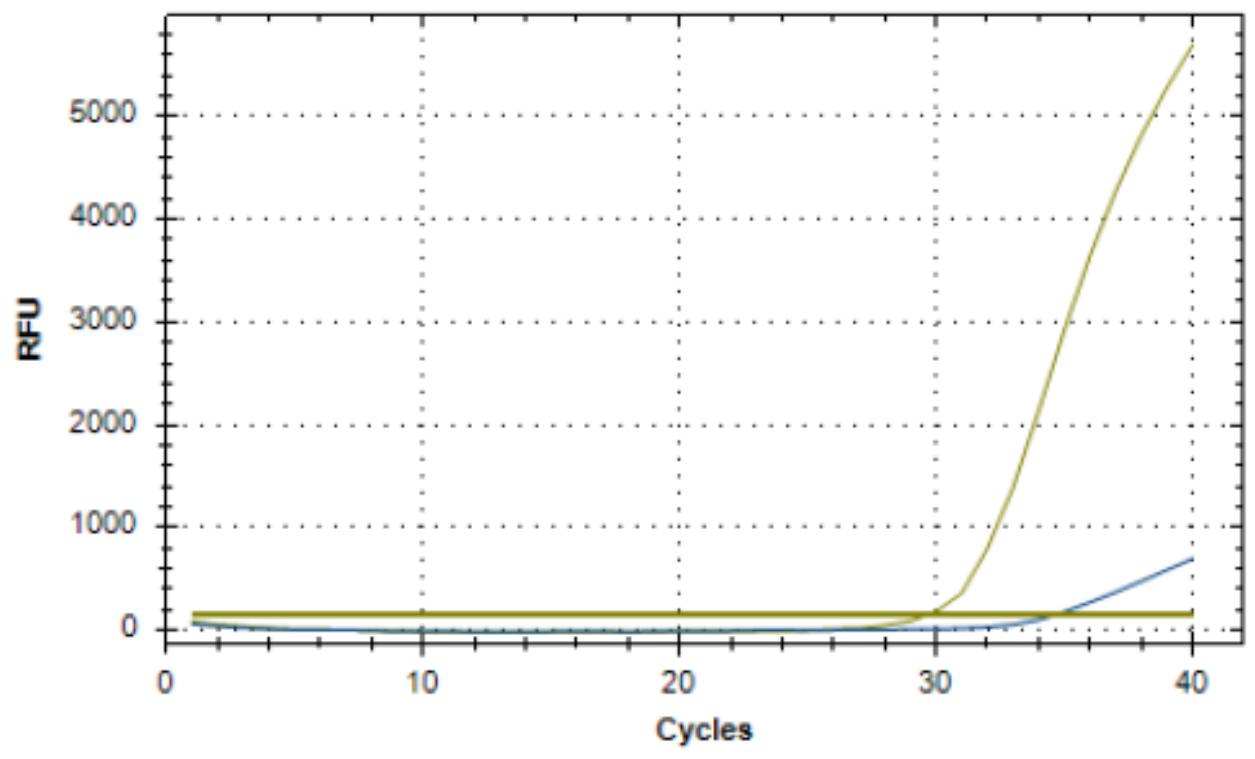

Gambar 1. Kurva kuas roti untuk target DNA babi dan vetebrata 


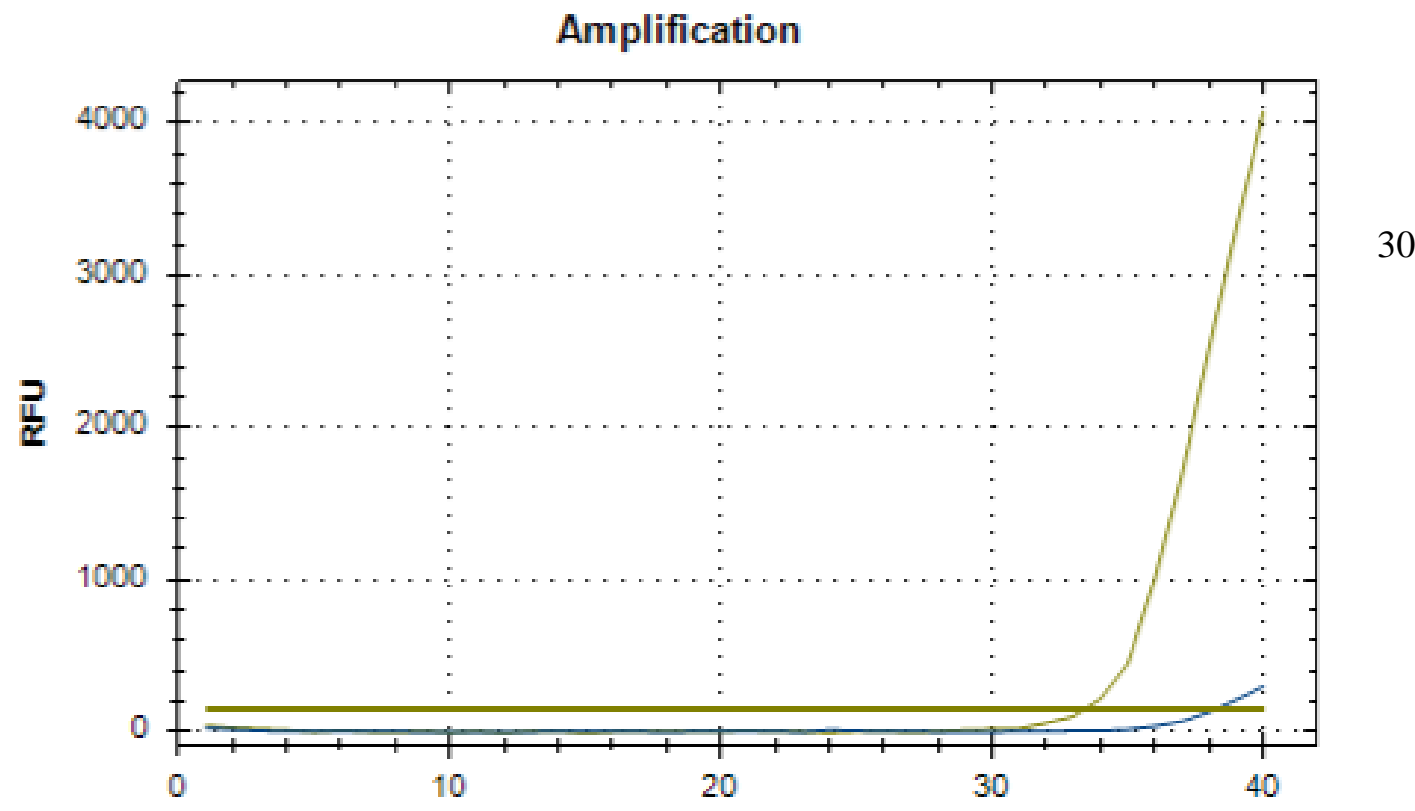

Gambar 2. Kurva day cream untuk target DNA babi dan vertebrata

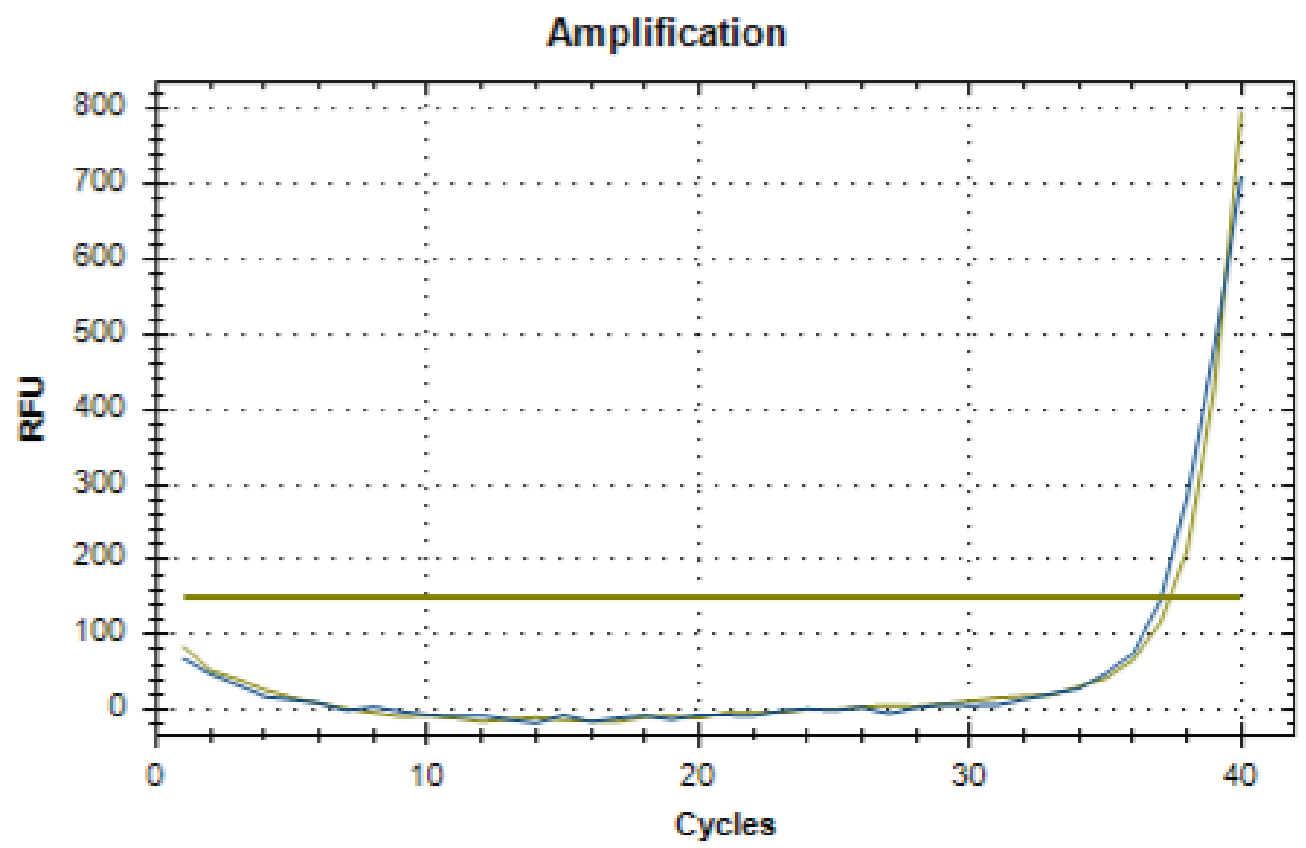

Gambar 3. Kurva sabun kecantikan untuk target DNA babi dan vertebrata

Gambar 1, 2, dan 3 menunjukkan sampel kuas roti, day cream, dan sabun kecantikan pada target DNA babi FAM yang ditunjukkan pada grafik biru menunjukkan hasil yang baik dan terjadi peningkatan dari hasil kontrol, begitu sebaliknya pada target DNA vetebrata ditunjukkan pada grafik hijau. Berdasarkan hasil di atas menunjukkan bahwa data hasil pengujian pada nilai $\mathrm{Ct}$ (Pig dan vetebrata) pada kontrol negtif diatas 38 dan kontrol positif \pm 30 . Sampel yang terdeteksi mengandung DNA babi memiliki kadar yang berbeda-beda, sehigga sampel dapat dihitung menggunakan rumus kalkulasi 
persentase DNA babi, didapatkan kandungan persentase yang dapat dilihat pada tabel 3 . Tabel 3. Persentase DNA babi pada sampel uji yang positif tercemar

\begin{tabular}{clccc}
\hline No. & Sampel & Cq FAM & Cq VIC & \% DNA babi \\
\hline 1. & Kuas roti & 34,60 & 29,61 & 3,15 \\
2. & Day cream & 38,23 & 33,40 & 3,52 \\
3. & Sabun Kecantikan & 37,04 & 37,36 & 124,83 \\
\hline
\end{tabular}

*Catatan : Nilai cut-off threshold FAM dan VIC yang digunakan adalah 150 RFU

\section{KESIMPULAN}

\section{Real Time Polymerase Chain} Reaction atau RT-PCR telah menjadi metode pengujian utama yang memiliki sensitivitas dan spesifitas yang tinggi, serta dapat mendeteksi sampel dalam jumlah yang banyak dan waktu yang singkat. Hasil tersebut dapat dilihat dari semua sampel yang diuji ekstrasi DNA babi didapatkan hasil konsentrasi berkisar antara 2,2-3,4 ng/ $\mu$ I. Dari hasil analisis RT-PCR dapat disimpulkan bahwa bahan baku yang dianalisis berupa kuas roti, day cream, dan sabun kecantikan mengandung bahan babi dengan persentase cemaran DNA babi sebesar 3,15-124,83\%.

\section{DAFTAR PUSTAKA}

Katadata, (2016), Indonesia, Negara berpenduduk muslim terbesar dunia, Http://databoks.katadata.co.id, diakses pada tanggal 15 April 2019.

Undang-Undang No. 33 Tahun 2014 tentang Jaminan Produk Halal (Lembaga Republik Indonesia Tahun 2014 Nomor 295 dan Tambahan Lembaga Republik Indonesia Nomor 5604).

Susanto, E., Wardoyo, (2014), Pengaruh substitusi daging babi terhadap karakteristik asam lemak sosis, Jurnal Ternak, Vol. 5, No. 02.

Husni, P., Putriana, N.A., Wicaksono, I.A., (2017), Metode Deteksi Kandungan
Babi dan Alkohol dalam Eksipien Farmasi dan Produk Obat untuk Menjamin Kehalalan Sediaan Obat, Majalah Farmasetika, Vol. 2 No. 1.

Keputusan Fatwa Musyawarah Nasional VI Majelis Ulama Indonesia Nomor: 2/MUNAS VI/MUI/2000 Tentang Penggunaan Organ Tubuh, Ari-ari, Air Seni Manusia Bagi Kepentingan Obatobatan dan kosmetika. 266-269.

Yusuf, Z.K., (2010), Polymerase Chain Reaction (PCR), Saintek Vol. 5 No. 6.

Hewajuli, D.A., NLPI, D., (2014), Perkembangan teknologi Reverse Transcriptase Chain Reaction dalam Mengidentifikasi Genom Avian Influenza dan Newcastle Diseases, Balai Besar Penelitian Veteriner.

Fadhlurrahman, Wardani, A.K., Widyastuti, E., (2015), Deteksi gelatin babi pada soft candy menggunakan metode PCR-RFLP sebagai salah satu pembuktian kehalalan pangan. Jurß̊ł Teknologi Pangan Vol. 16 No. 2, pp. 81-88.

Balia, R.L., Suryaningsih, L., dan Putranto, W.S., (2014), Pengujian pemalsuan bakso dengan daging babi melalui pendekatan ensimatis dan molekuler pada UKM di kawasan pendidikan Jatinangor Kabupaten Sumedang. Dharmakarya : Jurnal Aplikasi Ipteks untuk Masyarakat, Vol. 3 No. 2, pp. 70-72. 
Cai, H., Gung, X., Scnalan, M.S., Ramatlapeng, D.H., dan Lively C.R., (2012), Real Time-PCR Assays for Detection and Quantitation of Porcine and Bovine DNA in Gelatin Mixtures in Gelatin Capsule. Journal of food composition an analysis, 25: 83-87.

Amqizal, H.I.A., Al-Kahtani, H.A., Ismail E.A., Hayat, K., dan Jaswir, I., (2017), Identification and verification of porcine DNA in comercial gelatin and gelatin containing processed foods, Elsevier : Food control Vol 78 : 297303. 